\title{
Reduced production of interleukin 12 by interferon $\gamma$ primed alveolar macrophages from atopic asthmatic subjects
}

\author{
M J Plummeridge, L Armstrong, M A Birchall, A B Millar
}

\begin{abstract}
Background-Asthma is characterised pathologically by an inflammatory pulmonary infiltrate rich in $T$ helper (Th) 2 cells and eosinophils. Interleukin (IL)-12 is a heterodimeric cytokine critical for driving the development of uncommitted Th cells to express a Th 1 phenotype. Reduced pulmonary production of IL-12 may therefore play a role in the pathogenesis of asthma by contributing to the pulmonary cytokine imbalance seen in asthma.
\end{abstract}

Methods-IL-12 p70 protein levels in bronchoalveolar lavage fluid and p70 protein levels and IL-12 messenger RNA in alveolar macrophage cultures from normal and atopic asthmatic subjects were measured.

Results-There was a significant difference between the mean IL-12 p70 protein level in the bronchoalveolar lavage fluid from asthmatic subjects $(37.5 \mathrm{pg} / \mathrm{ml})$ and from normal subjects $(131 \mathrm{pg} / \mathrm{ml}, \mathrm{p}=$ 0.04). Alveolar macrophages from asthmatic subjects produced significantly less IL-12 protein $(30 \mathrm{pg} / \mathrm{ml})$ and messenger RNA than those from normal subjects $(69.5 \mathrm{pg} / \mathrm{ml}, \mathrm{p}<0.005)$. These differences were not caused by inhibition of IL-12 production by IL-10 nor to generalised hyporesponsiveness of asthmatic alveolar macrophages from subjects to the effects of interferon (IFN) $-\gamma$.

Conclusions-Pulmonary IL-12 production is lower in asthmatic subjects. This reduction is not the result of generalised hyporesponsiveness to IFN- $\gamma$. Reduced IL-12 levels may contribute to the development of asthmatic pulmonary inflammation through dysregulation of $\mathrm{Th}$ cell development.

(Thorax 2000;55:842-847)

Keywords: asthma; alveolar macrophages; interleukin 12; interferon $\gamma$

Asthma is characterised by an inflammatory infiltrate of the bronchial mucosa that is rich in $\mathrm{T}$ helper 2 (Th2) lymphocytes and cytokines which in turn both attract eosinophils and prolong their survival. ${ }^{1}$ Isotype switching to IgE production is initiated and the "allergic pattern" of inflammation seen in asthma is perpetuated. ${ }^{2}$ It is possible to relate the levels of Th2 cytokines to both the severity of clinical disease and the response to treatment. ${ }^{3}$
Factors controlling the development of the pulmonary $T$ cell response, including the differentiation of $\mathrm{Th}$ cells, are likely to be important in the pathogenesis of asthma. During the initiation of a $\mathrm{T}$ cell response, the cytokines present in the microenvironment of the $\mathrm{T}$ cell influence CD4+ Th subset development. An imbalance of these cytokines may result in a dysfunctional immune response.

Interleukin 12 (IL-12) is a $70 \mathrm{kD}$ heterodimeric cytokine produced predominantly by phagocytic and mature dendritic cells, but also by $\mathrm{B}$ lymphocytes and eosinophils. ${ }^{4-6}$ It is essential for the development of a $\mathrm{T}$ helper 1 (Th1) dominant immune response, leading to their production of interferon $\gamma($ IFN- $\gamma) .^{5}$ In addition to priming CD4+ $\mathrm{T}$ cells for high IFN- $\gamma$ production, IL-12 also contributes to their proliferation once they have differentiated into Th 1 cells. Additionally, if present in early clonal expansion, IL-12 primes T cells to produce high levels of IFN- $\gamma$ on re-stimulation. ${ }^{7}$ The production of IL-12 is itself upregulated in response to IFN- $\gamma$, the main inhibitor of this potent and potentially harmful positive feedback loop being IL-10. ${ }^{58}$

Animal studies have provided direct evidence for the role of IL-12 in the modification of asthma at both an immunological and a physiological level. IL-12 administered to animals with established allergic airways inflammation resulted in reduced airway hyperreactivity and reduced infiltration by eosinophils. ${ }^{9}$ In a mouse model of asthma, administration of IL-12 resulted in increased IFN- $\gamma$ levels and decreased IL-4 and IL-5 levels in the lungs, redressing the Th2/Th1 imbalance. ${ }^{10}$ There are few studies of IL-12 production in human lung tissue although there is evidence of reduced levels of IL-12 p40 mRNA expression in bronchial biopsy specimens from asthmatic subjects which increases following treatment with steroids, the cells expressing it being macrophages. ${ }^{11}$

The organ and cell type specificity of the immunological response emphasises the importance of the study of resident pulmonary cell function in asthma. The main source of IL-12 is phagocytic cells. The alveolar macrophage (AM) is the resident phagocytic cell of the lung and is therefore a potentially important pulmonary source of IL-12. Although originally described in larger airways, there is increasing evidence to support the involvement of more peripheral, including alveolar, tissue inflammation in asthma. ${ }^{12-14}$ In asthma both the pattern of AM cytokine production and their interaction with other cells of the immune sys- 
tem are abnormal. ${ }^{15}$ The production of IL-10, a potentially anti-inflammatory cytokine, by AMs from asthmatic subjects is reduced and this deficiency can be reversed by treatment with inhaled steroids. ${ }^{16}{ }^{17}$ AMs from subjects with atopic asthma but not from normal subjects enhance the production of the Th2 cytokine IL- 5 by CD4+ T cells. ${ }^{18}$ We hypothesised that there is abnormal production of IL-12 by the AM in asthma which may contribute to the pulmonary Th1/Th2 imbalance seen in this disease. The aims of the current study were to assess intrapulmonary IL-12 levels and spontaneous IL-12 production by AMs in asthmatic versus normal subjects. In addition, we looked at lipopolysaccharide (LPS)- and IFN- $\gamma$-induced expression of IL-12 in AMs to determine whether abnormal responses to these stimuli could account for altered IL-12 expression in these subjects.

\section{Methods}

SUBJECTS

Asthmatic subjects with a clinical history of asthma, reversible airflow obstruction with at least a $15 \%$ improvement in forced expiratory volume in one second $\left(\mathrm{FEV}_{1}\right)$, either spontaneously or after administration of inhaled $\beta_{2}$ agonist $(200 \mu \mathrm{g}$ albuterol), and increased airway responsiveness to histamine $\left(\mathrm{PD}_{20}<8 \mathrm{mg} / \mathrm{ml}\right)$ were included in the study. All were taking either $\beta_{2}$ agonists or received no medication. None had received inhaled or systemic corticosteroids for at least three months before the study or had ever undergone a course of immunotherapy. Skin prick responses to a panel of common aeroallergens were assessed with all atopic subjects exhibiting at least two positive responses. Patient characteristics are given in table 1 . Normal subjects had no history of asthma or other respiratory or allergic disease, normal pulmonary function, and were not atopic. All subjects were non-smokers or ex-smokers with a smoking history of $<3$ pack years. None had a history of respiratory tract infection in the two months preceding the study.

Ethical approval for the study was given by Southmead NHS Trust research ethics committee and written informed consent was obtained from all subjects.

\section{BRONCHOSCOPY}

Bronchoscopy was performed according to standard guidelines. Premedication with $2.5 \mathrm{mg}$ nebulised albuterol was given. Intravenous midazolam $(2.5-10 \mathrm{mg})$ with or without alfentanyl (250-500 $\mu \mathrm{g})$ was used as sedation. Nasal oxygen was administered throughout,

Table 1 Patient characteristics

\begin{tabular}{lll}
\hline & Atopic asthma & Normal \\
\hline Age (years) & $35(20-64)$ & $35(23-70)$ \\
M:F & $5: 3$ & $5: 5$ \\
BAL recovery $(\mathrm{ml})$ & $127.5(90-180)$ & $125(100-150)$ \\
Total cell count $\left(\times 10^{6} / \mathrm{ml}\right)$ & $5.54(1.3-10)$ & $6.4(2.5-12.2)$ \\
Differential cell count $(\%)$ & AM $90(80-95) \%$; Eo 5.7 & AM $>96 \%$ \\
& $(3-15) \%$, Lym $0.5(0-2) \%$ & \\
FEV $_{1}(\%$ predicted) & $82(72-100)$ & ND \\
Reversibility $(\%)$ & $17.75(15-27)$ & ND \\
\hline
\end{tabular}

Values are mean (range).

$\mathrm{AM}=$ alveolar macrophages $; \mathrm{Eo}=$ eosinophils $;$ Lym $=$ lymphocytes, $\mathrm{ND}=$ not done. and pulse oximetry performed continuously. After topical anaesthesia with $2 \%$ lidocaine, bronchoalveolar lavage (BAL) with four $60 \mathrm{ml}$ aliquots of buffered saline was performed into the (right) middle lobe. The BAL fluid was aspirated into a siliconised glass bottle and stored on ice until processing. Samples were processed within $15 \mathrm{~min}$ of collection. BAL samples were collected from a total of 10 normal subjects and eight atopic asthmatics. BAL details are given in table 1 .

ISOLATION OF ALVEOLAR MACROPHAGES

The chilled BAL fluid was strained through a single layer of coarse gauze to remove mucus clumps and then spun at $400 \mathrm{~g}$ for $5 \mathrm{~min}$ to recover cells. Filtered BAL fluid was collected and stored at $-80^{\circ} \mathrm{C}$ until analysis. The cell pellet was resuspended in serum-free RPMI 1640 medium (Sigma, Poole, UK) supplemented with $100 \mathrm{U} / \mathrm{ml}$ penicillin and $100 \mu \mathrm{g} /$ $\mathrm{ml}$ streptomycin (Sigma) and adjusted to $2 \times$ $10^{6} \mathrm{AMs} / \mathrm{ml}$ as defined by morphology. $100 \mu \mathrm{l}$ aliquots of the cell suspension were then plated out onto sterile 96 well plates (Gibco, Nunc, Denmark) for two hours. The non-adherent population was then removed by aspiration and $100 \mu \mathrm{l}$ of fresh RPMI added to each well. The resulting AM populations were $>95 \%$ pure in both asthmatic and normal populations with a viability of $>90 \%$ as assessed by Diff-Quik and trypan blue staining.

\section{CELL CULTURES}

Preincubation with interferon $\gamma(\mathrm{IFN}-\gamma)$ has previously been shown to increase macrophage IL-12 production. $^{8}$ To investigate the effect of IFN- $\gamma$ priming on AM IL-12 production, half of the AMs from each sample were preincubated overnight with 1000 units/ml IFN- $\gamma$ (PeproTech EC Ltd, London, UK) for 18 hours whilst the remaining half were cultured in medium alone. At the end of this period all cells were then cultured for a further 24 hours. For each experiment, to both the IFN- $\gamma$ primed cells and the non-primed cells were added either (1) medium alone (unstimulated), (2) LPS (E coli 0111:B4, $10 \mu \mathrm{g} / \mathrm{ml}$ ) or (3) anti-IL-10 antibody (JE53-19F1, $10 \mu \mathrm{g} /$ $\mathrm{ml})$. Anti-IL-10 antibody was added to neutralise the potential inhibitory effects of endogenous IL-10 on IL-12 production. The supernatants were then harvested and stored at $-80^{\circ} \mathrm{C}$ until analysis by ELISA

\section{RNA STUDIES}

For RNA studies, purified AMs were cultured at $1 \times 10^{6} / \mathrm{ml}$ in 24 well culture plates (Costar, Cambridge, USA). After preincubation with IFN $-\gamma$ as above, lipopolysaccharide (LPS) and anti-IL-10 antibodies were added as described above. RNA was harvested at six hours as determined by time course experiments.

RNA EXTRACTION

Total cellular RNA was extracted from cells using RNAzol B (AMS Biotechnology, Oxon, UK) according to manufacturer's instructions. The aqueous phase was transferred to a fresh tube and an equal volume of isopropanol was 
added. $1 \mu$ glycogen (Boehringer Mannheim, Germany) was added and the RNA precipitated at $-20^{\circ} \mathrm{C}$ overnight. The following morning samples were centrifuged at $12000 \mathrm{~g}$ for 15 $\min \left(4^{\circ} \mathrm{C}\right)$. The supernatant was removed and the RNA washed once with $75 \%$ ethanol by vortexing and subsequent centrifugation for 8 min at $7500 \mathrm{~g}\left(4^{\circ} \mathrm{C}\right)$. The RNA pellet was then air dried, resuspended in nuclease free water, and stored at $-80^{\circ} \mathrm{C}$.

\section{REVERSE TRANSCRIPTION POLYMERASE CHAIN} REACTION

RNA from cell samples was measured by densitometry at optical density (OD) $260 \mathrm{~nm}$ using a GeneQuant II (Pharmacia Biotech Ltd, Cambridge, UK). Reverse transcription was performed using a commercial kit (Promega Corp, Madison, USA). $1 \mu \mathrm{g}$ RNA was reverse transcribed according to manufacturer's instructions. IL-12 p35 and p40 primers were obtained from Oswel DNA Service (Southampton, UK) using published sequences designed to amplify cDNA but not genomic DNA. ${ }^{19}$ GAPDH primers were obtained from the same supplier. The sequences used are provided in table 2 . cDNA ( $1 \mu 1$ for GAPDH, $3 \mu \mathrm{l}$ for IL-12) was added to a $25 \mu \mathrm{l}$ reaction mixture comprising PCR buffer, $\mathrm{MgCl}_{2}$ (1.5 mM), dNTP $(0.2 \mathrm{mM})$, primers (40 ng) and $0.75 \mathrm{U}$ Taq polymerase. A thermocycler (GRI, UK) ran 30 cycles for IL-12 p35 and p40 and for GAPDH. Programmes used were $30 \mathrm{~s}$ denaturation at $94^{\circ} \mathrm{C}, 45 \mathrm{~s}$ annealing at $62^{\circ} \mathrm{C}$, and $45 \mathrm{~s}$ extension at $72^{\circ} \mathrm{C}$ for $\mathrm{GAPDH}$, and $30 \mathrm{~s}$ denaturation at $94^{\circ} \mathrm{C}, 45 \mathrm{~s}$ annealing at $60^{\circ} \mathrm{C}$, and $45 \mathrm{~s}$ extension at $72^{\circ} \mathrm{C}$ for IL-12 p35 and p40. The linearity of the system has been previously validated by serial dilution. The PCR products were then visualised using electrophoresis on $1.8 \%$ agarose gel stained with ethidium bromide.

ELISA

IL-12 p70

Supernatants were analysed for IL-12 p70 using an ELISA matched pair (Pharmingen, San Diego, CA, USA) according to manufacturer's instructions. This ELISA is specific for the potentially bioactive p70 heterodimer and there is no cross reactivity with either the free p35 or p40 subunits. ELISA plates (Gibco Nunc, Paisley, UK) were coated with $2 \mu \mathrm{g} / \mathrm{ml}$ coating antibody $(50 \mu \mathrm{l}$ per well) and incubated for 12 hours at $4^{\circ} \mathrm{C}$. The plates were washed three times on a platewasher with PBS containing $0.1 \%$ Tween 20 and subsequently blocked with PBS containing $0.5 \%$ BSA for one hour at $37^{\circ} \mathrm{C}$. The plates were then washed a further three times. Samples and standards were incubated for three hours at room

Table 2 Primer pairs for RT-PCR of alveolar macrophage $m R N A$

\begin{tabular}{lll}
\hline$c D N A$ & Primer pair & Size $(b p)$ \\
\hline IL-12 p35 & 5'-CCTCAGTTTGGCCAGAAACC & 295 \\
IL-12 p40 & 5'-GGTCTTTCTGGAGGCCAGGC & 355 \\
GAPDH & 5'-TGGGTCTATTGCAGGTGGAGG & 288 \\
& 5'-GCCAAAAGGGTCATCATGTC & \\
\hline
\end{tabular}

temperature. The plates were washed four times in wash buffer and $100 \mu \mathrm{l}$ of biotinylated detection antibody $(2 \mu \mathrm{g} / \mathrm{ml})$ was added to each well and incubated at room temperature for one hour and then washed four times with wash buffer.

SOLUBLE TNF-SR75

To determine whether there was generalised hyporesponsiveness to IFN- $\gamma$ we measured shedding of tumour necrosis factor receptor p75 (TNF-sR75), a known inducible product of IFN- $\gamma$ stimulation. ELISA plates were coated with $5 \mu \mathrm{g} / \mathrm{ml} 7 \mathrm{R} 10$ monoclonal antibody for p75 soluble receptor in coating buffer $(100 \mu \mathrm{l}$ per well) and incubated for 12 hours at $4^{\circ} \mathrm{C}$. This antibody (kindly provided by Dr Sue Stephens, Celltech Therapeutics, Slough, UK) showed no cross reactivity with other known cytokines, and its activity was not affected in the presence of human plasma or serum. The plates were then washed three times and blocked with PBS containing $0.5 \% \mathrm{BSA}$ for one hour at $37^{\circ} \mathrm{C}$. The plates were washed a further three times and samples were added, together with the recombinant p75 standards $(100 \mu \mathrm{l}$ per well) and the plates incubated for two hours at $37^{\circ} \mathrm{C}$. The plates were washed four times in wash buffer and $100 \mu \mathrm{l}$ of biotinylated TNF- $\alpha(50 \mathrm{ng} / \mathrm{ml})$ was added to each well. The plates were incubated for one hour at $37^{\circ} \mathrm{C}$ and then washed four times with wash buffer.

\section{ELISA DETECTION}

The bound cytokine/receptor was detected with streptavidin peroxidase in a dilution of 1:400 incubated for $30 \mathrm{~min}$ at room temperature. After washing four times, tetramethyl benzidine substrate was added and the plates were left to develop in the dark for $15 \mathrm{~min}$. The reaction was stopped with $1 \mathrm{M} \mathrm{H}_{2} \mathrm{SO}_{4}$ and the plates read on a plate reader (Dynatech MR 7000 ) at $450 \mathrm{~nm}$ (reference filter $630 \mathrm{~nm}$ ). Sample values were extrapolated from the standard curve using the Biolinx package (Dynatech, Billingshurst, UK). The lower limit of detection of this assay was determined as $16 \mathrm{pg} / \mathrm{ml}$ for IL-12 $\mathrm{p} 70$ and $70 \mathrm{pg} / \mathrm{ml}$ for soluble TNF receptor $\mathrm{p} 75$.

\section{STATISTICAL ANALYSIS}

The data were non-parametric, with the exception of the TNF-sR75 data. Assessment of significant differences within and between groups was therefore carried out by Wilcoxon signed rank and Mann-Whitney $U$ analysis, respectively, using a Minitab for Windows package. The TNF-sR75 data were compared using Student's $t$ test (paired for analysis within a group, unpaired for analysis between groups). A p value of $<0.05$ was considered significant.

\section{Results}

IL-12 P70 PROTEIN LEVELS

$B A L$ fluid

Significantly higher levels of IL-12 p70 protein were detected in the BAL fluid of normal subjects than in asthmatic subjects (median values $131 \mathrm{pg} / \mathrm{ml}$ and $37.5 \mathrm{pg} / \mathrm{ml}$, respectively (95\% CI 30.15 to 168.2 ), $\mathrm{p}=0.04$; fig 1 ). 


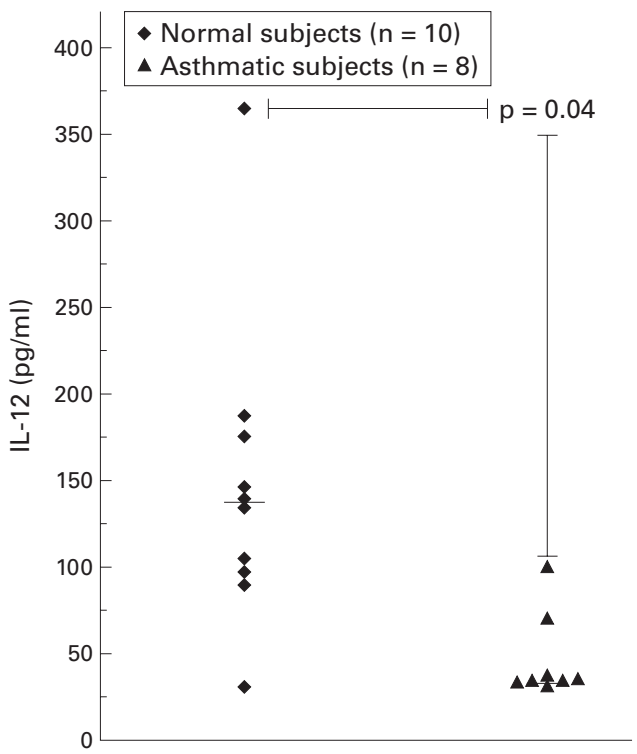

Figure 1 IL-12 p70 protein levels detected in the BAL fluid of normal and asthmatic subjects by ELISA. The horizontal bar denotes the median value.

\section{AM cultures}

Normal subjects: In AM cell culture experiments there was a significant increase in the production of IL-12 only in those cells pre-stimulated with IFN- $\gamma$. In AM cultures from normal subjects IL- 12 production was upregulated significantly by LPS following preincubation with IFN- $\gamma$ (control $=30 \mathrm{pg} / \mathrm{ml}$, IFN- $\gamma+$ LPS $=69.5 \mathrm{pg} / \mathrm{ml} ; \mathrm{p}<0.006$, fig 2$)$.

Asthmatic subjects: In contrast, there was no significant increase in IL-12 production by AMs from asthmatic subjects in response to LPS, either with or without IFN- $\gamma$ priming (fig 2). Production of IL-12 in response to LPS stimulation in cultures primed with IFN- $\gamma$ was significantly lower in asthmatic subjects than in normal subjects (asthmatics $=30 \mathrm{pg} / \mathrm{ml}$, normal subjects $=69.5 \mathrm{pg} / \mathrm{ml}(95 \%$ CI 14.0 to 61.0), $\mathrm{p}<0.005)$.

Effect of blocking endogenous IL-10: To determine whether the lower IL-12 levels in

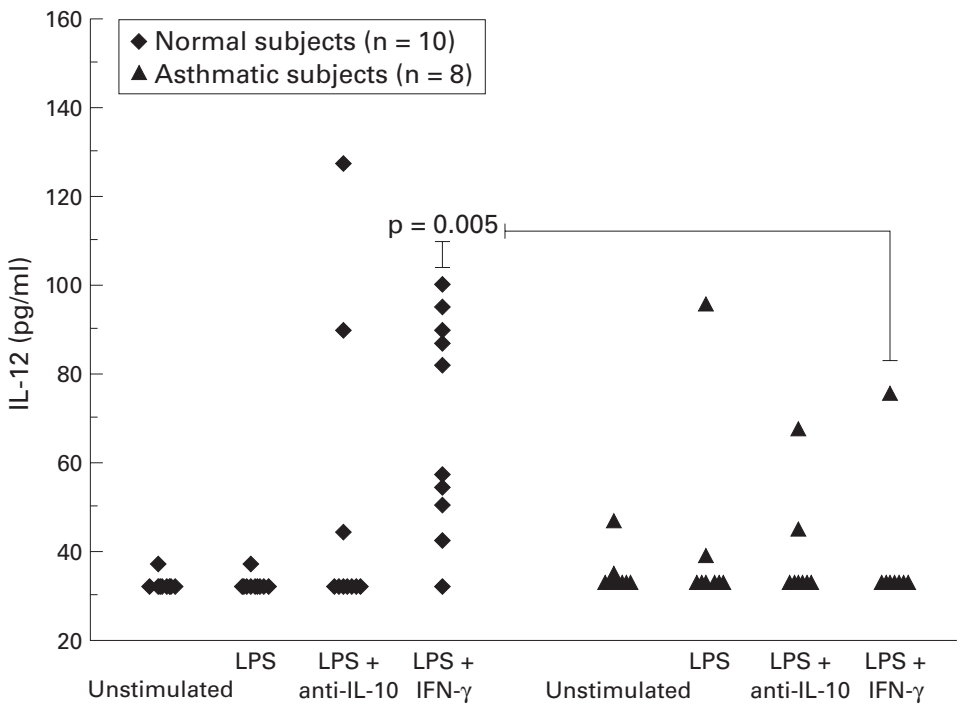

Figure 2 IL-12 p70 protein levels detected in 24 hour alveolar macrophage culture supernatants by ELISA. LPS = lipopolysaccharide; IFN- $\gamma=$ interferon $\gamma$.

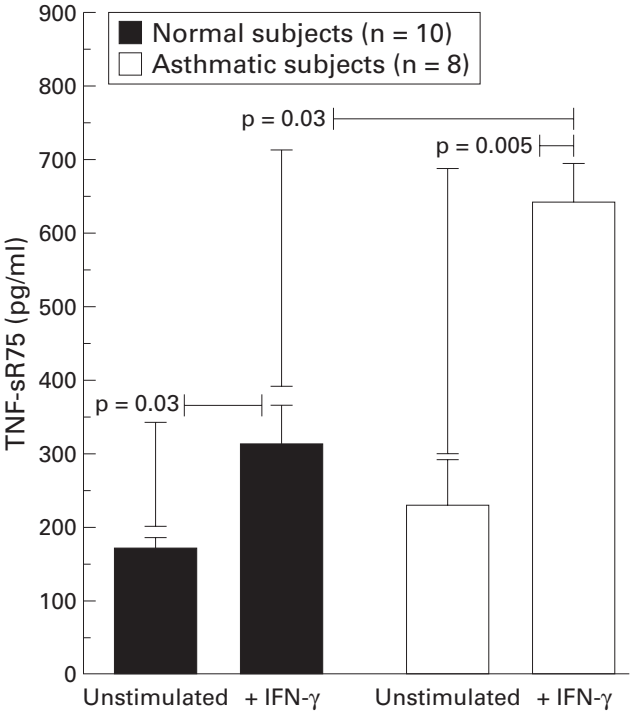

Figure $3 \quad T N F-s R 75$ protein levels detected in 24 hour alveolar macrophage supernatants by ELISA. Data are expressed as mean (SE).

asthmatic subjects resulted from increased endogenous production of IL-10 we stimulated AMs with LPS in the presence of anti-IL-10 antibody. This antibody had no significant effect on IL-12 production in either group (fig 2).

\section{$T N F-s R 75$}

To determine whether the reduced response to IFN- $\gamma$ in the asthmatic AMs was generalised hyporesponsiveness or specific to IL-12 induction, we measured shedding of TNF-sR75 which is a recognised consequence of IFN- $\gamma$ stimulation of AMs. ${ }^{20}$ There was a significant increase in production of TNF-sR75 in response to IFN- $\gamma$ by AMs from asthmatic subjects (mean (SE) 228 (61) pg/ml unstimulated, 641 (53) $\mathrm{pg} / \mathrm{ml}+$ IFN- $\gamma, \mathrm{p}=0.008$; fig 3). AMs from asthmatic subjects were not therefore refractory to stimulation by IFN- $\gamma$ and, in fact, produced significantly more TNFsR75 in response to IFN- $\gamma$ than those from normal subjects (311 (53) $\mathrm{pg} / \mathrm{ml}$ in normal subjects, $641(53) \mathrm{pg} / \mathrm{ml}$ in atopic asthmatic subjects, $\mathrm{p}=0.03$ ).

\section{RNA}

The PCR gels for GAPDH and IL-12 p35 and p40 are shown in fig 4 . In normal subjects mRNA production for IL-12 p40 was detectable following stimulation with LPS only after preincubation with IFN- $\gamma$. There was no detectable mRNA in unstimulated cells or in cells stimulated with either LPS or IFN- $\gamma$ alone in either group.

\section{Discussion}

This study is the first to show reduced IL-12 p70 production by AMs from asthmatic subjects. The reduction in both IL-12 p70 protein and mRNA for the IL-12 p35 and p40 subunits in subjects with asthma suggests altered regulation at the level of transcription. In this study, mRNA and subsequent protein 


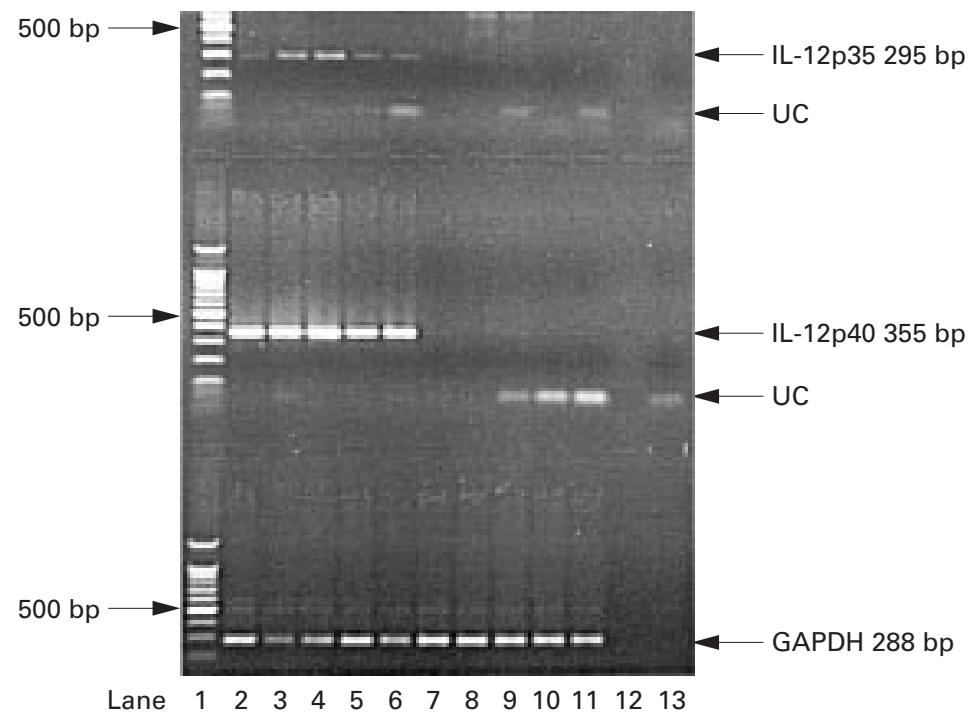

Figure 4 PCR analysis for GAPDH, IL-12 p35, and IL-12 p40 from alveolar macrophage samples co-stimulated with IFN- $\gamma(1000 \mathrm{U} / \mathrm{ml})+L P S(10 \mu \mathrm{g} / \mathrm{ml})$ from five normal and five asthmatic subjects. $U C=$ unincorporated primer. Lane $1=$ molecular weight marker, lanes $2-6=$ normal subjects, lanes $7-11=$ asthmatic subjects, lane $12=$ negative control, lane $13=$ no RT control.

production required priming with IFN- $\gamma$ before the addition of LPS, previously shown to be necessary for IL-12 production by normal human monocytes in vitro. ${ }^{5}$ There were significantly lower levels of mRNA for the p40 subunit compared with $\mathrm{p} 35$, consistent with the comparative excess in $\mathrm{p} 40$ production which is known to occur. ${ }^{2}$

The dependency on IFN- $\gamma$ priming which we observed in both subject groups contrasts with a recent study which showed IL-12 mRNA production by AMs in the presence of LPS alone. ${ }^{21}$ In that study AMs were collected from carcinoma resection specimens which may not necessarily have had normal characteristics. The AMs were also cultured with $10 \%$ FCS, a potential influence on cellular protein production. This may also explain the high IL-10 production in AMs and consequent effect of anti-IL-10 in comparison with this and previously published studies. ${ }^{17}$ More importantly, however, they were unable to detect the active p70 protein under these conditions. Another study has reported higher levels of IL-12 p40 production by AMs from untreated asthmatics in response to LPS stimulation alone. ${ }^{22}$ However, unlike the current study, the ELISA used did not measure the potentially bioactive p70 cytokine, but rather the p40 component. IL-12 p40 production may be 100 times that of IL-12 p70 and may not accurately reflect p70 production. $^{5}$

Study of the pulmonary compartment in asthma is important because cell and organ specific immune responses may differ from those observed in other cell types and cell lines. Our findings demonstrate an abnormality in IL-12 p70 production by cells within the pulmonary compartment of asthmatic subjects for the first time, and are consistent with reports highlighting differences in peripheral blood production of IL-12 in both atopic and other conditions. ${ }^{19}{ }^{23}$ In the current study IL-12 was detected in the BAL fluid of both groups.
Isolated AMs, however, did not produce IL-12 in vitro unless stimulated. It is therefore possible that AMs are not the main source of this cytokine in the BAL fluid. The possibility that non-adherent cells (including possible nonadherent AMs) discarded during purification had the potential to contribute significantly to in vitro IL-12 production is unlikely. However, to investigate this possibility we cultured mixed BAL cells from three normal subjects. Nonpurified mixed BAL cells in culture do not produce IL-12 unless stimulated. Dendritic cells may also be a source of IL-12, and the isolation and culture of these cells from human airways is the subject of ongoing research in our laboratory. Their ability to influence significantly BAL fluid cytokine levels is currently under investigation.

It is also possible that the collection, processing, and purification of AMs reduces their capacity to produce IL-12 in vitro, unless stimulated, to below the limits of detection used in these experiments. This possibility is supported by the observation that the purification of peripheral blood mononuclear cells (PBMCs) significantly impairs IL-12 production compared with that seen by PBMCs in whole blood, by a mechanism that is not as yet understood. ${ }^{23}$

AMs from asthmatic subjects show generally increased activation. ${ }^{24}$ Despite this, we considered the possibility that the lower level of IL-12 production by cultured AMs from asthmatic compared with normal subjects was due specifically to an impaired response to IFN- $\gamma$ during the initial priming period. We therefore measured supernatant levels of TNF-sR75 (CD 120b), which has previously been shown by ELISA to be specifically increased in AM cultures in response to IFN- $\gamma \cdot{ }^{20}$ AMs from asthmatic subjects were responsive to IFN- $\gamma$, suggesting that global refractoriness to IFN- $\gamma$ stimulation could not explain our results. In keeping with previous reports of generally increased AM activation in asthma, ${ }^{15} \mathrm{AMs}$ from asthmatic subjects produced significantly more TNF-sR75 than those from normal subjects. There are several possible explanations for this finding. One possibility is that sensitivity to IFN- $\gamma$ stimulation is different for TNF-sR75 and IL-12. IFN- $\gamma$ signal transduction has been very well characterised ${ }^{25}$ and it is known that there is only one signalling pathway for IFN- $\gamma$ inducible genes, which is mediated through JAK1 and JAK2 activation and STAT1 phosphorylation. Activation of the intracellular signal requires the presence of both the $\alpha$ and $\beta$ subunit. The $\alpha$ subunit is involved with ligand binding and contains the JAK 1 and STAT 1 binding sites, whereas the $\beta$ subunit plays no part in ligand binding but is required to stabilise the receptor binding complex. The $\beta$ subunit also contains the JAK2 binding site. Although different transduction pathways cannot account for the altered responsiveness to IFN- $\gamma$ in asthmatic subjects, it is possible that the signalling thresholds for TNF-sR75 and IL-12 induction are not the same. This threshold could be influenced by altered expression of either the $\alpha$ or $\beta$ subunits, or altered expression of the intracellular signal 
transduction proteins. Recent studies have shown that the phenotype of AMs and macrophage derived monocytes from asthmatic subjects differs from normal subjects ${ }^{26}$ and, although IFN- $\gamma$ receptor expression has not been explored in this context, such investigation is warranted.

Since IL-10 is an IFN- $\gamma$-inducible gene, we explored the possibility that endogenous IL-10 could account for low IL-12 levels in our asthmatic subjects. However, inhibition of endogenous IL-10 activity resulted in no significant effect on IL-12 production. This was not an unexpected finding since it has previously been observed that the levels of IL-10 in AM cultures from asthmatic subjects are lower than in normal subjects. ${ }^{17}$

AM mediated suppression of the immune response, and maintenance of a dynamic equilibrium between pro-inflammatory and antiinflammatory mediators by the AM, are likely to be important in maintaining immunological homeostasis in the lung. ${ }^{28}{ }^{29}$ In asthma, inappropriately reduced IL-12 production by the $\mathrm{AM}$ in response to a stimulus may play a part in the initiation and maintenance of Th2 dominated airway inflammation seen in this disease.

A recent study has shown enhancement of IL-5 production by CD4+ T cells by AMs from patients with atopic asthma.$^{18}$ In a murine model of asthma both airway hyperresponsiveness and pulmonary eosinophilia following provocation are CD4+ $\mathrm{T}$ cell dependent. ${ }^{30}$ Factors controlling CD4+ T cell development, such as IL-12, are therefore likely to be important in asthma. Our finding of lower IL-12 production by AMs from asthmatic subjects suggests a direct mechanism by which the AM may influence the local microenvironment, potentially controlling both the development of CD4+ $\mathrm{T}$ lymphocytes and their subsequent response on re-stimulation, thus upsetting the balance that usually exists between $\mathrm{T}$ helper cell subsets. Furthermore, pre-existing differentiated Th1 cells could both proliferate and produce cytokines suboptimally as IL-12 is required for this function during antigen presentation to T cells. ${ }^{31}$

In conclusion, this study has shown lower IL-12 protein and mRNA production by AMs from asthmatic subjects than from healthy subjects. Our observations support further the potential role of the AM in the development of the pulmonary inflammation associated with asthma, and suggest one mechanism to explain why the production of $\mathrm{Th} 2$ cytokines by lymphocytes in asthma is increased.

Dr Martin Plummeridge is supported by a grant from GlaxoWellcome plc. Dr Lynne Armstrong is supported by a grant from Action Research.

1 Robinson DS, Hamid Q, Ying S, et al. Predominant 作 asthma. $N$ Engl f Med 1992;326:298-304.

2 Humbert M, Durham SR, Ying S, et al. IL-4 and IL-5 mRNA and protein in bronchial biopsies from patients with atopic and non-atopic asthma: evidence against with atopic and non-atopic asthma: evidence against "intrinsic" asthma being a distinct immunopatholo

3 Robinson D, Hamid Q, Ying S, et al. Relationships among Robinson D, Hamid Q, Ying S, et al. Relationships among numbers of bronchoalveolar lavage cells expressing messenger ribonucleic acid for cytokines, asthma symptoms,
and airway metacholine responsiveness in atopic asthma. $\mathscr{f}$ Allergy Clin Immunol 1993;92:397-403.
4 Kobayashi M, Fitz L, Ryan M, et al. Identification and purification of natural killer cell stimulatory factor (NKSF), a cytokine with multiple biologic effect
phocytes. $\mathcal{F}$ Exp Med 1989;170:827-45.

5 Trinchieri G. Immunobiology of interleukin-12. Immunol Res 1998;17:269-78.

6 Grewe M, Czech W, Morita A, et al. Human eosinophils produce biologically active IL-12: implications for control of T cell responses. F Immunol 1998;161:415-20.

7 Manetti R, Parronchi P, Giudizi MG, et al. Natural killer cell stimulatory factor (interleukin-12 (IL-12)) induces T helper 1 (Th1)-specific immune responses and inhibits the helper 1 (Th1)-specific immune responses and inhibits the 177:1199-204.

8 Hayes MP, Wang J, Norcross MA. Regulation of interleukin-12 expression in human monocytes: selective priming by interferon- $\gamma$ of lipopolysaccharide-inducible p35 and p40 genes. Blood 1995;86:646-50.

9 Kips JC, Brusselle GG, Joos GF, et al. Interleukin-12 inhibits antigen-induced airway hyper-responsiveness in mice. Am $\mathcal{F}$ Respir Crit Care Med 1996;153:535-9.

10 Gavett S H, O'Hearn D J, Li X, et al. Interleukin-12 inhibits antigen-induced airway hyperresponsiveness, inflammation and Th2 cytokine expression in mice. 7 Exp Med 1995;182:1527-36.

11 Naseer T, Minshall EM, Leung DM, et al. Expression of IL-12 and IL-13 mRNA in asthma and their modulation in response to steroid therapy. Am f Respir Crit Care Med 1997; 155:845-51.

12 Minshall E, Hogg JC, Hamid QA. Cytokine mRNA expression in asthma is not restricted to the large airways. $\mathcal{F}$ Allergy Clin Immunol 1998;101:386-90.

13 Kraft M, Djukanovic R, Wilson S, et al. Alveolar tissue inflammation in asthma. Am $\mathcal{f}$ Respir Crit Care Med 1996;154:1505-10.

14 Kraft M, Martin RJ, Wilson S, et al. Lymphocyte and eosinophil influx into alveolar tissue in nocturnal asthma. Am 7 Respir Crit Care Med 1999;159:228-34.

15 Viksman MY, Liu MC, Richel CA, et al. Phenotypic analysis of alveolar macrophages and monocytes in allergic airway inflammation: 1 Evidence for activation of alveolar macrophages but not PBMCs in subjects with allergic macrophages but not PBMCs in subjects with allergic
rhinitis and asthma. Am $\mathcal{F}$ Respir Crit Care Med 1997;155: rhinitis and

16 Borish L, Aarons A, Rumbyrt J, et al. Interleukin-10 regulation in normal subjects and patients with asthma. F Allergy Clin Immunol 1996;97:1288-96.

17 John M, Lim S, Seybold J, et al. Inhaled corticosteroids increase interleukin-10 but reduce macrophage inflammatory protein-1 $\alpha$, granulocyte-macrophage colonystimulating factor and interferon- $\gamma$ release from alveolar macrophages in asthma. Am $\mathcal{F}$ Respir Crit Care Med 1998;157:256-62.

18 Tang C, Rolland JM, Li X, et al. Alveolar macrophages from atopic asthmatics, but not atopic nonasthmatics, enhance interleukin- 5 production by CD $4+\mathrm{T}$ cells. Am $\mathcal{7}$ Respir Crit Care Med 1998;157:1120-6.

19 Harrison TS, Lvitz SM. Role of Il-12 in peripheral blood mononuclear cell responses to fungi in persons with and without HIV infection. F Immunol 1996;156:4492-7.

20 Galve de Rochemonteix B, Nicod LP, Dayer JM. Tumour necrosis factor soluble receptor 75: the principal receptor form released by human alveolar macrophages and monocytes in the presence of interferon gamma. Am F Respir Cell Mol Biol 1996;14:279-87.

21 Isler P, Galve de Rochemonteix B, Spongeon F, et al. Interleukin-12 production by human alveolar macrophages is controlled by the autocrine production of interleukin-10. Am ₹ Respir Cell Mol Biol 1999;20:270-8.

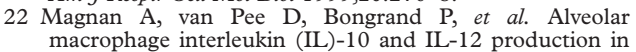
macrophage interleukin (IL) -10 and 1I

23 van der Pouw Kraan TCTM, Boeije LCM, de Groot ER, et al. Reduced production of IL-12 and Il-12 dependent FN- $\gamma$ in patients with allergic asthma. $\mathcal{f}$ Immunol 1997;158:5560-5.

24 Plummeridge $M$, Millar AB. The pulmonary macrophage and asthma. Clin Asthma Rev 1998;2:103-7.

25 Bach EA, Aguet M, Schreiber RD. The IFN- $\gamma$ receptor: a paradigm for cytokine receptor signaling. Ann Rev Immunol 1997;15:563-91.

26 Lensmar C, Prieto J, Dahlen B, et al. Airway inflammation and altered alveolar macrophage phenotype pattern after and altered alveolar macrophage phenotype pattern after repeated low-dose allergen exposure of atopic

27 Tormey VJ, Leonard C, Faul J, et al. Dysregulation of monocyte differentiation in asthmatic subjects is reversed by IL-10. Clin Exp Allergy 1998;28:992-8.

28 Spiteri MA, Knight RA Jeremy JY, et al. Alveolar macrophage-induced suppression of peripheral mononuclear cell responsiveness is reversed by in vitro allergen exposure in bronchial asthma. Eur Respir f 1994;7:1431-8.

29 Martin TR. Cytokines and the acute respiratory distress syndrome (ARDS): a question of balance. Nature Med 1997;3:272-3

30 Gavett SH, Chen X, Finkelman F, et al. depletion of murine $\mathrm{CD} 4+\mathrm{T}$ lymphocytes prevents antigen-induced airway hyperreactivity and pulmonary eosinphilia. Am f Respir Cell Mol Biol 1994;10:587-93.

31 Maruo S, Toyo-oka K, Oh-hora M, et al. IL-12 produced by antigen-presenting cells induces IL-2-independent proliferation of T helper cell clones. F Immunol 1996;156:1748 55 . 